\title{
KORELASI ANTARA KECERDASAN LOGIS MATEMATIS DENGAN KOMPETENSI INTI PENGETAHUAN MATEMATIKA SISWA
}

\author{
Ni Luh Desy Asri Antari ${ }^{1}$, I Wyn Sujana ${ }^{2}$, I Nengah Suadnyana ${ }^{3}$ \\ 1,2,3 Jurusan Pendidikan Guru Sekolah Dasar \\ Universitas Pendidikan Ganesha \\ Singaraja, Indonesia \\ Email : desyasriantari@gmail.com ${ }^{1}$, iwayan.sujana@undiksha.ac.id $^{2}, \underline{\text { inengah.suadnyana@undiksha.ac.id }}^{3}$
}

\begin{abstract}
Abstrak
Penelitian ini bertujuan untuk mengetahui korelasi yang signifikan antara kecerdasan logis matematis dengan kompetensi inti pengetahuan matematika siswa kelas V. Penelitian ini adalah penelitian ex post facto jenis korelasional. Populasi dari penelitian ini adalah siswa kelas V SD Gugus Letkol Wisnu Kecamatan Denpasar Utara Tahun Pelajaran 2017/2018 yang memiliki populasi 340 orang. Penentuan sampel menggunakan teknik proporsional random sampling dengan taraf signifikan 5\% dan diperoleh banyak sampel dari populasi adalah 172 orang. Data diperoleh dari hasiltes uraian kecerdasan logis matematis dan pencatatan dokumen kompetensi inti pengetahuan matematika siswa. Sebagai uji prasyarat adalah uji normalitas sebaran data. Setelah terpenuhi prasyarat tersebut, berikutnya adalah uji hipotesis menggunakan analisis korelasi product moment. Berdasarkan hasil analisis maka $r_{\mathrm{xy} \text { hitung }}=0,472$. Pada taraf signifikan $5 \%$ dengan $n=172$, maka diperoleh $r_{x y \text { tabel }}=0,148$. Karena $r_{x y \text { hitung }}>r_{\text {xy tabel }}=0,472>0,148$ maka dapat diartikan bahwa $H_{0}$ yang berbunyi tidak terdapat korelasi yang signifikan antara kecerdasan logis matematis dengan kompetensi inti pengetahuan matematika siswa kelas V SD Gugus Letkol Wisnu Kecamatan Denpasar Utara ditolak dan $H_{a}$ diterima. Jadi dapat disimpulkan bahwa terdapat korelasi yang signifikan antara kecerdasan logis matematis dengan kompetensi inti pengetahuan matematika siswa kelas V SD Gugus Letkol Wisnu Kecamatan Denpasar Utara Tahun Pelajaran 2017/2018, dengan arah korelasi positif, artinya semakin tinggi kecerdasan logis matematis maka semakin tinggi pula kompetensi inti pengetahuan matematika yang diperoleh siswa.
\end{abstract}

Kata kunci: kecerdasan logis matematis, kompetensi inti pengetahuan, matematika

\section{Abstract}

This study aimed to determine the significant correlation between the logical mathematical intelligence with the core competency of knowledge of mathematics students of grade $\mathrm{V}$. This research is ex post facto research with correlation type. The population of this study is a class $V$ student residing in SD Gugus Letkol Wisnu, North Denpasar Lesson Year 2017/2018 which has a population of 340 people. Determination of the sample used proportional random sampling technique with significant level $5 \%$ and obtained the number of samples from the population is 172 people. The data were obtained through results of the essay test of the logical mathematical intellegence and the document recording of the core competency of knowledge of mathematics student. As the test is a normality test data distribution. After all prerequisite tests are met, the statistical analysis used in this next study is hypothesis test using product moment correlation analysis. Based on result of analysis then $r_{x y \text { hitung }}=0,472$. At the significant levelof $5 \%$ with $n=$ 172 , then obtained $r_{x y}$ tabel $=0.148$. Because $r_{x y \text { hitung }}>r_{x y}$ tabel $=0.472>0.148$ it can be interpreted that $\mathrm{H}_{\mathrm{o}}$ which reads there is not significant correlation betweenthe logical mathematical intelligence with the core competency of knowledge of mathematics students of grade V SD Gugus Letkol Wisnu, North Denpasar, in the Lesson Year 2017/2018 is rejected and $\mathrm{H}_{\mathrm{a}}$ accepted. So it can be concluded that there is a significant correlation between the logical mathematical intelligence with the core competency of knowledge of mathematics students of grade V SD Gugus Letkol Wisnu, North Denpasar, in the Lesson Year 2017/2018, with a positive correlation direction, meaning the higher logical mathematical intelligence then the higher the core competency of knowledge of mathematics students. 


\section{Keywords :Logical mathematical intelligence, the core competency of knowledge, mathematic \\ 1. Pendahuluan}

Pengembangan kurikulum merupakan bagian yang sangat esensial dalam keseluruhan kegiatan pendidikan dan menjadi suatu acuan atau peraturan yang dijadikan pedoman dalam pelaksanaannya. Kurikulum ibarat jantung pendidikan, sebab kurikulum merupakan alat yang sangat penting bagi keberhasilan suatu pendidikan, tanpa kurikulum yang tepat maka tujuan dan sasaran dari pendidikan sulit untuk dicapai.

Pendidikan di Indonesia saat ini menerapkan Kurikulum 2013, Kurikulum ini merupakan serentetan raingkaian penyempurnaan terhadap Kurikulum yang telah dirintis tahun 2004 yang berbasis kompetensi lalu diteruskan dengan Kurikulum 2006 (KTSP). Salah satu hal pokok dalam Kurikulum 2013 adalah menekankan pada pembelajaran siswa aktif. Dalam hal ini, peran guru sangat signifikan dalam upaya mensukseskan tujuan Kurikulum 2013 tersebut. Sehingga dalam Kurikulum 2013 lebih menuntut kemampuan guru dalam berpengetahuan dan mencari tahu pengetahuan sebanyak-banyaknya.

Sekolah Dasar (SD) sebagai jenjang pendidikan formal yang terendah menyelenggarakan pendidikan bagi siswa melalui berbagai macam kegiatan. Kegiatan pendidikan di SD dilaksanakan di dalam kelas maupun di luar kelas yang dilakukan melalui bermacam-macam mata pelajaran. Matematika merupakan salah satu mata pelajaran yang wajib diberikan di SD. Hal ini mengacu pada Peraturan Pemerintah No. 32 Tahun 2013 Pasal 77l Ayat 1.

Matematika merupakan mata pelajaran yang sangat penting dan perlu diberikan untuk membekali peserta didik dengan kemampuan berpikir logis, analitis, sistematis, kritis dan kreatif, serta kemampuan bekerjasama. Namun pada kenyataannya, masih terdapat banyak masalah yang berkaitan dengan mata pelajaran matematika. Rendahnaya minat siswa untuk menekuni matematika salah satunya disebabkan oleh adanya image yang mengganggu pikiran sebagian besar siswa bahwa matematika adalah pelajaran yang sangat rumit. Selanjutnya, rendahnya prestasi matematika dibuktikan dengan hasil observasi dan wawancara pada siswa kelas V SD di Gugus Letkol Wisnu rata-rata matematika masih perlu ditingkatkan. Didukung oleh hasil-hasil penelitian masih menunjukkan bahwa "Proses pembelajaran matematika di sekolah dasar masih belum menunjukkan hasil yang memuaskan" (Susanto, 2013:191). Selain itu faktor yang mempengaruhi prestasi belajar siswa adalah kecerdasan (Jayantika, 2013). Artinya seseorang akan mencapai keberhasilan pada bidang pendidikan jika memiliki kecerdasan akademik yang tinggi. Dilanjutkan pada penelitian Jayantika menyatakan, bertolak dari ketidaksetujuaan akan pandangan ini Gardner melakukan penelitian bahwa seseorang memiliki lebih dari satu kemampuan untuk dikembangkan. Pada dasarnya kemampuan otak manusia memiliki tingkat kecerdasan yang berbeda-beda. Berdasarkan hal ini dapat dikatakan bahwa tidak ada siswa yang bodoh, yang ada adalah siswa yang menonjol dalam satu atau berbagai bidang. Setiap orang memiliki delapan kecerdasan, salah satunya adalah kecerdasan logis matematis.

Berhubungan dengan kecerdasan, adapun dalam pembelajaran di sekolah guru belum memperhatikan kecerdasan majemuk pada masing-masing anak khusunya adalah kecerdasan logis matematis dan hasil belajar dari anak perlu mendapat kajian dari guru, sehingga melalui kajian ini guru akan mengetahui tingkat kecerdasan yang dimiliki pada masing-masing anak didiknya. Dari uaraian tersebut, maka dilakukan penelitian dengan judul "Korelasi Antara Kecerdasan Logis Matematis dengan Kompetensi Inti Pengetahuan Matematika Siswa Kelas V SD Gugus Letkol Wisnu Kecamatan Denpasar Utara Tahun Pelajaran 2017/2018".

\section{Metode}

Penelitian ini menggunakan rancangan penelitian ex post facto. Menurut Kerlinger tahun 1973 (dalam Emzir 2011) ex post factoadalah penyelidikan empiris yang sistematis di mana ilmuwan tidak mengendalikan variabel tersebut telah terjadi, atau karena variabel tersebut pada dasarnya tidak dapat dimanipulasi. merupakan metode penemuan empiris yang dilakukan 
secara sistematis, peneliti tidak melakukan kontrol terhadap variabel-variabel bebas karena manifestasinya sudah terjadi atau variabel-variabel tersebut secara inheren tidak dapat dimanipulasi. Maka penelitian yang akan dilakukan ini tergolong "ex post facto" jenis korelasi.

"Korelasi adalah suatu bentuk analisis data dalam penelitian yang bertujuan untuk mengetahui kekuatan atau bentuk arah hubungan di antara dua variabel atau lebih, dan besarnya pengaruh yang disebabkan oleh variabel satu (variabel bebas) terhadap variabel lainnya (variabel terikat)" (Siregar, 2015:200). Menurut Netra (1974:157) "Korelasi berarti hubungan timbal balik". Jadi dapat disimpulkan korelasi merupakan dua buah variabel yaitu varibel bebas dan variabel terikat yang memiliki hubungan timbal balik bersifat asosiatif. Variabel bebas dalam penelitian ini adalah kecerdasan logis matematis $(X)$, sedangkan variabel terikat dalam penelitian ini adalah kompetensi inti pengetahuan matematika pada siswa kelas $\mathrm{V}$ SD (Y).

Populasi dalam penelitian ini adalah siswa kelas V SD Gugus Letkol Wisnu Kecamatan Denpasar Utara Tahun Pelajaran 2017/2018 yang berjumlah 340 siswa.Setelah mengetahui populasi pada kelas V SD Gugus Letkol Wisnu Kecamatan Denpasar Utara langkah selanjutnya adalah menentukan sampel penelitian.

Menentukan sampel dapat dilihat pada tabel Issac and Michael. Pada tabel tersebut dijelaskan tentang besarnya sampel yang diambil dari populasi dengan tingkat kesalahan $1 \%$, $5 \%$, dan 10\% (Sugiyono, 2016). Sesuai dengan tabel tersebut, pada jenjang pendidikan digunakan tingkat kesalahan 5\%, jumlah populasi kelas V SD Gugus Letkol Wisnu Kecamatan Denpasar Utara Tahun Pelajaran 2017/2018 sebanyak 340 orang, pada tabel Issac and Michaeldengan jumlah populasi di kelas V SD Gugus Letkol Wisnu Kecamatan Denpasar Utara Tahun Pelajar 2017/2018 sebanyak 340 orang, jadi jumlah sampel yang diambil dengan tingkat kesalahan $5 \%$ adalah 172 orang.

"Pada pengambilan sampel untuk penelitian ini menggunakan teknik sampling untuk menentukan sampel yang akan digunakan. Teknik sampling adalah teknik pengambilan sampel" (Sugiyono, 2016:118). Prosedur yang ditempuh dilakukan dengan jalan mengambil individu yang terdapat dalam masing-masing kategori populasi, sesuai dengan proporsi atau perimbangan untuk dijadikan sampel penelitian.

Menurut Agung (2014) "Sampel proporsional atau sampel berimbang merupakan teknik sampling yang dilakukan untuk lebih menjamin representatif sampel jika ternyata subjek yang terdapat dalam strata atau tiap wilayah tidak sama". Random merupakan penentuan anggota sampel dari populasi dilakukan secara acak. Yang artinya seluruh siswa mendapat kesempatan yang sama untuk dijadikan sampel dalam penelitian. Cara pengambilan sampel secara random dalam penelitian ini dilakukan dengan menggunakan undian nomor absen siswa. Dengan demikian dalam penelitian ini, penentuan sampel menggunakan teknik proporsional random sampling ialah teknik menentukan sampel secara acak dengan memperhatikan jumlah siswa dari masing-masing kelas.

Kualitas dan hasil penelitian dipengaruhi oleh dua hal utama yaitu, kualitas instrumen penelitian dan kualitas pengumpulan data. Metode pengumpulan data dapat dilakukan dengan berbagai cara (Sugiyono, 2014). Terdapat 2 jenis metode pengumpulan data, yaitu dengan tes dan non-tes. Tes adalah alat atau prosedur yang dipergunakan dalam rangka pengukuran dan penilaian (Sudijono, 2005:66). Sependapat dengan Arikunto (2010:193) "tes adalah serentetan pertanyaan atau latihan serta alat lain yan digunakan untuk mengukur keterampilam, pengetahuan intelegensi, kemampuan atau bakat yang dimiliki oleh individu atau kelompok. Jadi dari kedua pendapat tersebut dapat disimpulkan bahwa tes merupakan teknik pengumpulan data berupa seperangkat rangsangan (stimulus) yang diberikan kepada seseorang untuk mengetahui pengetahuan, kemampuan, bakat, dan kepribadian seseorang tersebut.

Pernyataan tersebut tidaklah harus diartikan bahwa teknik tes adalah satu-satunya teknik untuk melakukan evaluasi hasil belajar, sebab masih ada teknik lainnya yang dapat dipergunakan, yaitu teknik non-tes. Non-tes adalah prosedur penilaian yang ditujukan untuk menilai hasil belajar dari aspek tingkah laku seperti menilai aspek afektif aspek keterampilan (psikomotorik) (Amirono dan Daryanto, 2016:71). 
Metode pengumpulan data yang akan dilakukan pada penelitian di Gugus Letkol Wisnu Kecamatan Denpasar Utara, yaitu menggunakan instrumen tes. Teknik tes yang digunakan dalam penelitian ini adalah teknik tes uraian (essay test).

Instrumen yang digunakan dalam mengumpulkan data variabel terikat atau kompetensi inti pengetahuan matematika pada penelitian ini adalah pencatatan dokumentasi untuk mendapatkan data kompetensi inti pengetahuan matematika siswa kelas V SD Gugus Letkol Wisnu Tahun Pelajaran 2017/2018. Dokumen merupakan catatan peristiwa yang sudah berlalu. "Dokumen bisa berupa bentuk tulisan, gambar, atau karya-karya monumental dari seseorang" (Sugiyono, 2009:329). Menurut Agung (2012:65) "pencatatan dokumen merupakan cara memperoleh data dengan jalan mengumpulkan segala macam dokumen dan melakukan pencatatan secara sistematis". Jadi dapat disimpulkan pencatatan dokumentasi adalah cara memperoleh data dengan mengumpulkan catatan atau barang-barang tertulis dari seseorang yang sudah berlalu.

Hasil belajar yang diukur dalam penelitian ini adalah kompetensi inti pengetahuan matematika pada aspek kognitif dari nilai UAS matematika siswa kelas $\mathrm{V}$ pada semester 1. variabel bebas adalah variabel yang mempengaruhi atau menjadi sebab munculnya variabel terikat. Instrumen yang digunakan dalam mengumpulkan data variabel bebas atau kecerdasan logis matematis pada penelitian ini adalah tes uraian yang terdiri dari 5 butir soal.

Definisi operasional variabel yaitu suatu definisi yang diberikan kepada suatu variabel atau kontrak dengan cara memberikan arti, atau mempersentasikan kegiatan, ataupun memberikan suatu oprasional yang diperlukan untuk mengukur konstrak atau variabel tersebut. Berikut ini adalah definisi oprasional dari masing-masing variabel penelitian. Kecerdasan logis matematis merupakan kemampuan berpikir dengan menggunakan logika, rasional, dan masuk akal. Kecerdasan logis matematis ini menekankan pada kegiatan berpikir yang bersifat terukur, kuantitatif, dan analisis. Di dalam pembelajaran menekankan pada kemampuan dalam penalaran, mengurutkan, berpikir dalam pola sebab akibat, menciptakan hipotesis, mencari keteraturan konseptual atau pola numerik, mencirikan sesuatu berdasarkan sebab akibat, pengelompokan, melalui proses klasifikasi, atau identifikasi.

Dalam penelitian ini untuk menguji kevalidan butir tes uraian kecerdasan logis matematis, peneliti menggunakan validitas logis. Arikunto, (2015:81) "ada dua macam validitas logis yaitu: validitas isi dan validitas konstrak". Berikut ini adalah penjelasan mengenai validitas isi dan validitas kostrak. Uji validitas isi dilakukan dengan cara menyesuaikan butir tes esai kecerdasan logis matematis dengan indikator. Uji validitas isi ini dilakukan dengan membuat kisi-kisi pernyataan. Validitas isi ialah derajat dimana sebuah tes mengukur cakupan substansi yang ingin diukur (Sukardi, 2013:123). Sedangkan Arikunto (2015:82) mengatakan validitas isi merupakan tujuan khusus tertentu untuk mengukur sejajar dengan materi atau isi pelajaran yang diberikan. Kesimpulan dari validitas isi ialah dimana sebuah alat ukur untuk menentukan sejajar dengan materi atau isi pelajaran. Menguji validitas konstrak, dapat digunakan pendapat dari para ahli (judgment experts). Setelah instrument dikonstruksi tentang aspek-aspek yang akan diukur dengan dilandaskan teori tertentu, hasil tersebut akan dikonstruksikan kepada para ahli. Jumlah ahli yang digunakan minimal 3 orang (Sugyono, 2014). Setelah melalui proses review oleh ahli, instrumen mengalami perbaikan sesuai saran ahli.

Syarat kedua yang harus digunakan dalam pengujian suatu instrumen yaitu uji reliabilitas. Reliabilitas suatu instrumen merujuk kepada kadar stabilitas dan konsistensi instrumen tersebut (Yusuf, 2015:74). Pengukuran reliabilitas instrumen penelitian ini dengan menggunakan tes berpikir kreatif dengan menggunakan rumus Alpha. Setelah mendapatkan data tentang kecerdasan logis matematis, selanjutnya akan diuji kompetensi inti pengetahuan matematika. Untuk di uji hipotesis korelasi antara kecerdasan logis matematis dengan kompetensi inti pengetahuan matematika.

Pada penelitian ini, metode analisis yang digunakan adalah metode analisis statistik deskriptif dan metode analisis statistik inferensial. Kegiatan akhir yang dilakukan setelah seluruh data terkumpul sesuai dengan fokus penelitian adalah analisis data. Adapun teknik analisis data yang digunakan diuraikan sebagai berikut metode analisis deskriptif yang dapat dibedakan menjadi dua jenis yaitu kuantitatif dan kualitatif. Penelitian ini menggunakan metode analisis deskriptif kuantitatif. Melalui analisis statistik deskriptif kuantitatif pada penelitian ini 
cara yang dilakukan untuk pengolahan datanya adalah dengan menerapkan rumus mean (ratarata) dan SD (Standar Deviasi).

Metode analisis statistik inferensial yang dilakukan adalah uji hipotesis. Hipotesis yang diuji pada penelitian ini adalah hubungan antara kecerdasan logis matematis dengan kompetensi inti pengetahuan matematika. Untuk memenuhi persyaratan uji hipotesis, maka diperlukan persyaratan analisis, yaitu uji normalitas dan untuk menguji normalitas sebaran digunakan formula Chi-Kuadrat. Kriteria yang digunakan adalah dengan membandingkan harga Chi-Square hitung dengan Chi-Square tabel pada taraf signifikan 5\%. Jika harga ChiSquare hitung lebih kecil atau sama dengan harga Chi-Square tabel $\left(\mathrm{X}_{\mathrm{h}}^{2} \leq \mathrm{X}_{\mathrm{t}}^{2}\right)$ maka, distribusi data dinyatakan normal. Sebaliknya juga harga Chi-Square hitung lebih besar harga Chi-Square tabel $\left(\mathrm{X}_{\mathrm{h}}^{2}>\mathrm{X}_{\mathrm{t}}^{2}\right)$ maka, dinyatakan tidak normal (Sugiyono, 2016). Setelah diketahui data berdistribusi normal, pengujian hipotesisnya dilakukan dengan menggunakan teknik korelasi product moment. Adapun hipotesis yang diuji dalam penelitian ini yaitu hipotesis nol $\left(\mathrm{H}_{0}\right)$ yang berbunyi tidak terdapat korelasi yang signifikan antara kecerdasan logis matematis dengan kompetensi inti pengetahuan matematika siswa kelas V SD Gugus Letkol Wisnu Tahun Pelajaran 2017/2018. Ketentuan kriteria yang digunakan dalam hasil analisis yaitu, apabila $r_{x y}$ hitung $>r_{x y}$ tabel, maka $\mathrm{H}_{0}$ yang berbunyi tidak terdapat korelasi yang signifikan antara kecerdasan logis matematis dengan kompetensi inti pengetahuan matematika siswa kelas V SD Gugus Letkol Wisnu Kecamatan Denpasar Utara Tahun Pelajaran 2017/2018 ditolak dan sebaliknya, apabila $r_{x y}$ hitung $\leq r_{x y}$ tabel maka $H_{0}$ yang berbunyi tidak terdapat korelasi yang signifikan antara kecerdasan logis matematis dengan kompetensi inti pengetahuan matematika siswa kelas V SD Gugus Letkol Wisnu Kecamatan Denpasar Utara Tahun Pelajaran 2017/2018 diterima. Kofisien korelasi merupakan suatu angka yang menunjukkan ukuran kuntitatif korelasi antara variabel yang dikorelasikan. Angka koefisen korelasi bergerak dari $-1,00$ (negatif 1) sampai dengan $+1,00$ (positif 1). Korelasi yang baik adalah korelasi yang baik adalah korelasi yang menunjukan +1 (Agung, 2016). Besar kecilnya koefisien korelasi itu memberi petunjuk atau arah kepada peneliti terhadap besar kecilnya korelasi antara kedua gejala tersebut.

Arah korelasi dapat dibedakan menjadi 3 macam yaitu, positif, negatif dan nol.Netra (1974:159) menjelaskan "dikatakan positif apabila perubahan yang satu menunjukan arah yang sama dengan perubahan pada gejala yang lain, korelasi negatif yaitu apabila perubahan ada gejala yang satu menunjukan arah yang berlawanan dengan perubahan pada gejala yang lain , dan korelasi nol yaitu apabila perubahan pada gejala tersebut menunjukianarah yang beraturan.

Dapat disimpulkan bahwa arah korelasi merupakan arah atau petunjuk untuk mengetahui besar kecilnya korelasi antara kedua gejala tersebut. Hipotesis yang diuji dalam penelitian ini yaitu hipotesis nol $\left(\mathrm{H}_{0}\right)$ yang berbunyi tidak terdapat korelasi yang signifikan antara kecerdasan logis matematis dengan kompetensi inti pengetahuan matematika siswa kelas V SD Gugus Letkol Wisnu Kecamatan Denpasar Utara Tahun Pelajaran 2017/2018. Rumus yang digunakan untuk menganalisis yaitu korelasi product moment.

Ketentuan kriteria yang digunakan dalam hasil analisis menurut Supardi (2016) yaitu: Jika $r_{x y}$ hitung $>r_{x y}$ tabel maka hipotesis yang berbunyi tidak terdapat korelasi yang signifikan antara kecerdasan logis matematis dengan kompetensi inti pengetahuan matematika siswa kelas V SD Gugus Letkol Wisnu Kecamatan Denpasar Utara Tahun Pelajaran 2017/2018 $\left(\mathrm{H}_{0}\right)$ ditolak dan sebaliknya, jika $r_{x y}$ hitung $\leq r_{x y}$ tabel maka hipotesis yang berbunyi tidak terdapat korelasi yang signifikan antara kecerdasan logis matematis dengan kompetensi inti pengetahuan matematika siswa kelas V SD Gugus Letkol Wisnu Kecamatan Denpasar Utara Tahun Pelajaran 2017/2018 $\left(\mathrm{H}_{0}\right)$ diterima. 


\section{Hasil dan Pembahasan}

Hasil penelitian ini memaparkan mengenai data kecerdasan logis matematis sebagai variabel bebas $(X)$ dan data kompetensi inti pengetahuan matematika sebagai variabel terikat (Y) yang ditampilkan grafik.

Dari data kecerdasan logis matematis dapat dilihat dalam bentuk grafik berikut.

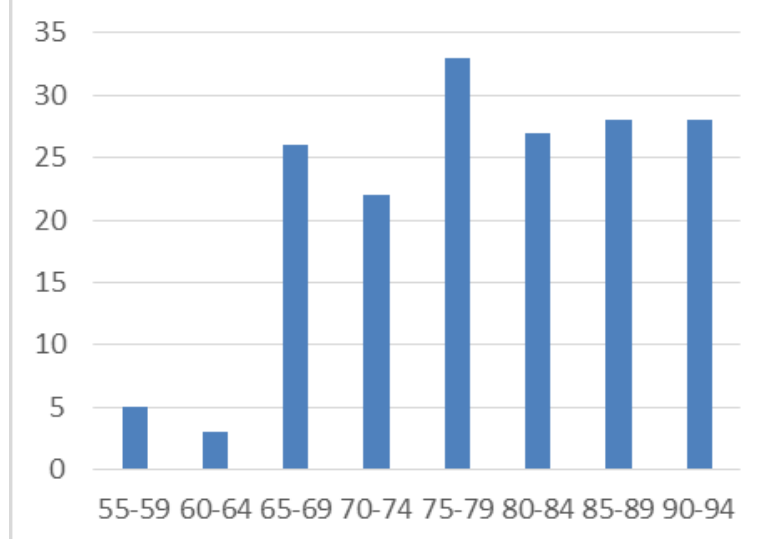

Gambar 1. Histogram Data Kecerdasan Logis Matematis

Data kecerdasan logis matematis dapat diketahui bahwa frekuensi nilai terbanyak terdapat pada interval ke-5, selanjutnya dapat dilihat data berikut ini tentang tingkat kategori kecerdasan logis matematis siswa SD di Gugus Letkol Wisnu, Denpasar Utara.

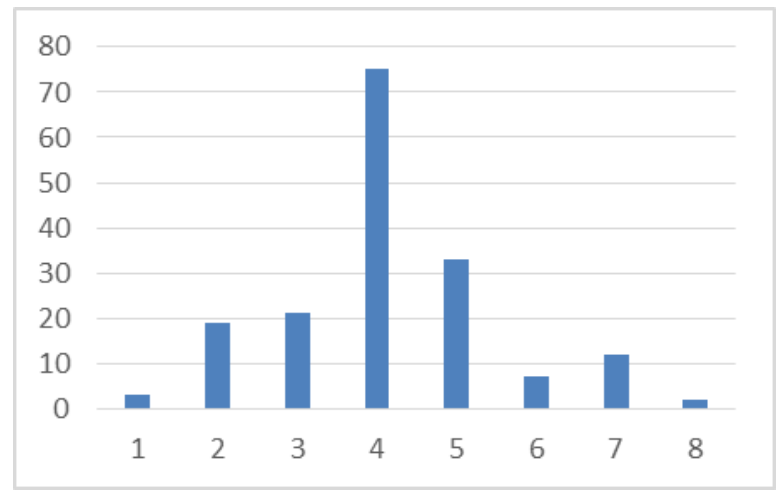

Gambar 2. Histogram Data Nilai Ulangan Akhir Semester 1 Kompetensi Inti Pengetahuan Matematika

Data nilai ulangan akhir semester 1 kompetensi inti pengetahuan matematikadapat diketahui bahwa frekuensi nilai terbanyak terdapat pada interval ke-4, selanjutnya dapat dilihat data berikut ini tentang tingkat kategori kompetensi inti pengetahuan matematika siswa SD di Gugus Letkol Wisnu Kecamatan Denpasar Utara.

Pada interval ke-4, rerata dari kategori kompetensi inti pengetahuan matematika siswa adalah 77,67 dan nilai tersebut berada pada nilai PAP rentang 65-79. Maka dapat disimpulkan bahwa kompetensi inti matematika siswa kelas V di SD Gugus Letkol Wisnu Kecamatan Denpasar Utara tergolong cukup baik.

Langkah selanjutnya adalah uji prasyarat yaitu Uji Normalitas kecerdasan logis matematis menggunakan teknik uji Chi-Kuadrat $\left(\mathrm{x}^{2}\right)$. Nilai dari variabel $\mathrm{X}$ atau kecerdasan logis matematis dapat dikatakan berdistribusi normal apabila $x^{2}{ }_{\text {hitung }} \leq x^{2}$ tabel. Langkah - langkah melakukan uji normalitas kecerdasan logis matematis $(X)$ dengan menggunakan tabel penolong. 
Hasil uji normalitas kecerdasan logis matematis yaitu berdasarkan analisis diperoleh $x_{\text {hitung }}^{2} 10,690$, dan menggunakan taraf signifikan 5\%, jika dimasukkan ke dalam kriteria $x^{2}{ }_{\text {hitung }}$

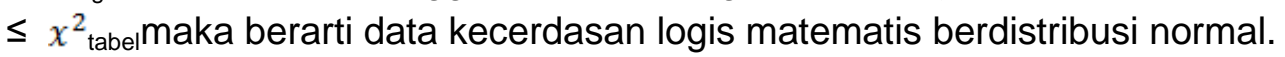

Uji Normalitas kompetensi inti pengetahuan matematika menggunakan teknik uji ChiKuadrat $\left(x^{2}\right)$. Nilai dari variabel $\mathrm{Y}$ atau kompetensi inti pengetahuan matematika dapat dikatakan berdistribusi normal apabila $x^{2}$ hitung $\leq x^{2}$ tabel. Berdasarkan analisis maka diperoleh $\mathrm{x}_{\text {hitung }}^{2}=6,77$, dan menggunakan taraf signifikan $5 \%$, jika dimasukkan ke dalam kriteria $x^{2}$ hitung $\leq x_{\text {tabel }}^{2}$ maka data kompetensi inti pengetahuan matematika berdistribusi normal.

Uji hipotesis yang dilakukan adalah uji hipotesis dengan teknik menggunakan analisis product moment (variabel $\mathrm{X}$ dengan $\mathrm{Y}$ ). Pengujian hipotesis perlu adanya hipotesis alternatif $\left(\mathrm{H}_{\mathrm{a}}\right)$, maka untuk tujuan analisis data akan dirumuskan juga hipotesis nol $\left(\mathrm{H}_{0}\right)$, karena dalam statistika yang diuji adalah hipotesis nol $\left(\mathrm{H}_{0}\right)$.

Adapun hipotesis yang akan dirumuskan sebagai berikut.

$\mathrm{H}_{0} \quad$ : tidak terdapat korelasi yang signifikan antara kecerdasan logis matematis dengankompetensi inti pengetahuan matematika pada siswa kelas V SD Gugus Letkol Wisnu Denpasar utara tahun pelajaran 2017/2018

Untuk uji koefisien korelasi, digunakan nilai tabel product moment $\left(r_{x y}\right.$ tabel $)$ untuk $n=172$, pada taraf signifikansi $5 \%$ diperoleh nilai $r_{x y}$ tabel adalah 0,148 sebagai pembanding sedangkan $r_{x y \text { hitung }}$ diperoleh sebesar 0,472. Maka dapat dinyatakan $r_{x y h i t u n g}>r_{x y}$ tabelyaitu $0,472>0,148$ ini berarti nilai $r_{x y h i t u n g}$ signifikan dengan nilai 0,472 ini berarti $\mathrm{H}_{\mathrm{a}}$ yang berbunyi terdapat korelasi yang signifikan antara kecerdasan logis matematis dengan kompetensi inti pengetahuan matematika pada siswa kelas V SD Gugus Letkol Wisnu Kecamatan Denpasar Utara Tahun Pelajaran 2017/2018 diterima.

Hal ini menunjukan bahwa terjadi korelasi yang kuat antara kecerdasan logis matematis dengan kompetensi inti pengetahuan matematika pada siswa kelas V SD Gugus Letkol Wisnu Denpasar Utara Tahun Pelajaran 2017/2018. Sedangkan arah korelasi, memiliki arah korelasi yang positif berarti semakin tinggi kecerdasan logis matematis maka semakin meningkat kompetensi inti pengetahuan matematika yang diperoleh siswa.

Berdasarkan hasil analisis yang diperoleh sebelumnya $r_{x y}$ hitung $>r_{x y}$ tabel, sehingga terdapat korelasi yang signifikan antara kecerdasan logis matematis dengan kompetensi inti pengetahuan matematika Kelas V SD Gugus Letkol Wisnu Kecamatan Denpasar Utara Tahun Pelajaran 2017/2018. Berdasarkan uraian tersebut dapat diinterpretasi, bahwa rata-rata siswa yang mempunyai kecerdasan logis matematis dapat memperoleh kompetensi inti pengetahuan matematika yang lebih tinggi.

Berdasarkan uraian tersebut kita dikemukakan interpretasi, bahwa rata-rata siswa yang tergolong memiliki kecerdasan logis matematis, siswa memiliki nilai kompetensi inti pengetahuan yang kuat atau tinggi dalam pembelajaran serta memiliki pandangan yang luas dan minat yang tinggi dalam mengikuti pembelajaran.

Pada penelitian ini diperoleh $r_{\text {hitung }}=0,472$ dengan $r_{\text {tabel }}$ pada taraf signifikansi $5 \%$ dengan $\mathrm{n}=172$, nilai $r_{\text {tabel }}$ adalah 0,148 . Hal ini berarti $r_{\text {hitung }}>r_{\text {tabel }}$ yang sejalan dengan penelitian Sukada (2013) yang menyatakan bahwa semakin tinggi skor kecerdasan logis matematis yang dicapai siswa maka semakin tinggi pula kompetensi inti pengetahuan matematika yang dicapai siswa tersebut, ditunjukkan dengan hasil pengujian hipotesis melalui persamaan garis regresi $\hat{y}=47,629+0,249 X_{3}(F=8,303, P<0,05)$ ini yang berarti koefisien regresi yang diperoleh adalah bermakna. Ini menunjukan bahwa naik turunnya hasil belajar matematika siswa disebabkan oleh naik turunnya kecerdasan logis matematika siswa. Dari hasil penelitian ini menunjukkan terdapat korelasi positif antara variabel kecerdasan logis matematis dan variabel kompetensi inti pengetahuan matematika.

\section{Simpulan dan Saran}


Hasil analisis menunjukkan bahwa terdapat korelasi yang signifikan antara kecerdasan logis matematis dengan kompetensi inti pengetahuan matematika siswa kelas V SD Gugus Letkol Wisnu Kecamatan Denpasar Utara Tahun Pelajaran 2017/2018. Kategori yang diperoleh termasuk dalam kategori korelasi yang kuat antara kecerdasan logis matematis dengan kompetensi inti pengetahuan matematika. Arah korelasinnya adalah positif karena nilai $r$ positif, berarti semakin tinggi kecerdasan logis matematis maka semakin meningkat kompetensi inti pengetahuan matematika.

Berdasarkan hasil analisis dengan menggunakan microsoft excel dan menghitung manual, diperoleh $r_{\text {hitung }}=0,472$ dengan taraf signifikansi $5 \%$ dan $n=172$ diperoleh nilai $r_{\text {tabel }}$ sebesar $=0,148$ yang berarti $r_{\text {hitung }}>r_{\text {tabel }}$ sehingga $\mathrm{H}_{\mathrm{a}}$ yang berbunyi terdapat korelasi yang signifikan antara kecerdasan logis matematis dengan kompetensi inti pengetahuan matematika siswa kelas V SD Gugus Letkol Wisnu Kecamatan Denpasar Utara tahun pelajaran 2017/2018 diterima.

Berdasarkan uraian tersebut berarti rata-rata siswa yang tergolong memiliki kecerdasan logis matematis, mampu dalam meningkatkan kompetensi pengetahuan matematika. Pengertian tersebut dapat diartikan, semakin tinggi siswa memiliki kecerdasan logis matematis, maka semakin tinggi kompetensi inti pengetahuan yang dimiliki siswa khususnya dalam pengetahuan matematika. Jadi dapat disimpulkan bahwa hubungan antara kecerdasan logis matematis dengan kompetensi inti pengetahuan matematika memiliki arah korelasi positif pada kategori korelasi yang sedang.

Adapun saran yang disampaikan sebagai berikut.Berdasarkan temuan penelitian yang diperoleh, disarankan kepada siswa untuk menumbuhkan kecerdasan logis matematis yang lebih baik, agar siswa dapat meningkatkan penguasaan kompetensi inti pengetahuan matematika siswa. Kepada guru agar lebih menumbuhkan kecerdasan logis matematis yang dimiliki siswa sehingga tujuan pembelajaran tercapai secara optimal. Kepada kepala sekolah agar dapat menggunakan hasil penelitian ini sebagai pendukung sumber belajar guru dalam meningkatkan kualitas pembelajaran dengan menumbuhkan kecerdasan logis siswa dalam belajar di sekolah sehingga sekolah mampu menghasilkan siswa yang berkualitas. Kepada peneliti agar hasil penelitian ini digunakan sebagai referensi untuk melaksanakan penelitian selanjutnya dan semoga penelitian ini bermanfaat bagi seluruh elemen masyarakat yang menggunakan penelitian ini.

\section{Daftar Pustaka}

Agung, A.A. Gede. 2012. Metodologi Penelitian Pendidikan. Singaraja: Universitas Pendidikan Ganesha.

Agung, A.A. Gede. 2013. Evaluasi Pendidikan. Singaraja: Universitas Pendidikan Ganesha.

Agung, A.A. Gede. 2014. Metodologi Penelitian Pendidikan. Singaraja: Universitas Pendidikan Ganesha.

Agung, A.A. Gede. 2016. Statistika Dasar untuk Pendidikan Edisi Pertama Cetakan Pertama. Yogyakarta: Deepublish.

Amirono dan Daryanto. 2016. Evaluasi dan Penilaian Pembelajaran Kurikulum 2013. Yogyakarta: Gava Media

Arikunto, Suharsimi. 2010. Prosedur Penelitian Suatu Pendekatan Praktik. Jakarta: PT Rineka Cipta. 
Arikunto, Suharsimi. 2015. Dasar-dasar Evaluasi Pendidikan. Jakarta: PT Bumi Aksara

Armstrong, Thomas. 2013. Kecerdasan Multipel di Dalam Kelas Edisi Ketiga. Jakarta. Indeks

BSNP. 2016. Peraturan Menteri Pendidikan Nasional Nomor 22 Tahun 2006 Tanggal 23 Mei 2006 Standar Isi. Jakarta: Menteri Pendidikan Nasional

Dantes. 2017. Desain Eksperimen dan Analisis Data. Depok: PT Rajagrafindo Persada

Darmadi, Hamid. 2011. Metode Penelitian Pendidikan dan Sosial. Bandung: Alfabeta.

Emzir. 2011. Metodologi Penelitian Pendidikan Kuantitatif dan Kualitatif. Jakarta: PT Rajagrafindo Persada.

Jayantika, I. G. A. N. Trisna. 2013. “Kontribusi Bakat Numerik ,KecerdasanSpasial, dan Kecerdasan Logis Matematis Terhadap Prestasi Belajar Matematika Siswa SD Negeri di Kabupaten Buleleng", Volume 2, Nomor1.http://pasca.undiksha.ac.id/ejournal/index.php/JPM/article/view/81/732

Kamus Besar Bahasa Indonesia daring, dilihat 19 Januari 2018. http://kbbi.kemendikbud.go.id/entri/dokumen/>.

Karso, dkk. 2014. Pendidikan Matematika 1. Tangerang Selatan: Universitas Terbuka.

Kurniasih, Imas dan Berlin Sani. 2014. Sukses Mengimplementasikan Kurikulum 2013. Kata Pena.

Kosasih, E. 2014. Strategi Belajar dan Pembelajaran Implementasi Kurikulum 2013. Bandung: Penerbit Yrama Widya.

Koyan, I Wayan. 2012. Statistik Teknik Analisis Data Kuantitatif. Singaraja: Universitas Pendidikan Ganesha.

Lestari, Karunia Eka dan Yudhanegara, Mokhammad Ridwan. 2017 Penelitian Pendidikan Matematika. Bandung: PT Refika Aditama.

Musfiqon, H.M. 2012. Metodologi Penelitian Pendidikan. Jakarta: Prestasi Pustaka Publisher.

Netra, I.B. 1974. Statistik Inferensial. Surabaya: Usaha Nasional.

Permendikbud. Nomor 24 Tahun 2016. Peraturan Menteri Pendidikan dan Kebudayaan Republik Indonesia Nomor 24 Tahun 2016 Tentang Kompetensi Inti dan Kompetensi Dasar Pelajaran. Pada kurikulum 2013 Pada Pendidikan Dasar Dan Pendidikan Menengah .Jakarta: Kementerian

Pendidikan dan Kebudayaan.

PP. Nomor 32 Tahun 2013. Peraturan Pemerintah Republik Indonesia Nomor 32 Tahun 2013 Tentang Perubahan Atas Peraturan Pemerintah Nomor 19 Tahun 2005 Tentang Standar Nasional Pendidikan. Jakarta: Presiden Republik Indonesia

Satyawati, Ni Nyoman Sri Budi. 2011. "Pengaruh Model Pembelajaran Penemuan Terbimbing Berbasis LKS Terhadap Hasil Belajar Matematika Siswa Ditinjau Dari Kecerdasan Logis 
Matematis Pada Siswa Kelas X SMA N 1 Bangli", Volume 2, Nomor 2http://pasca.undiksha.ac.id/e-journal/index.php/JPM/article/view/981/732

Setyosari, Punaji. 2015. Metode Penelitian Pendidikan dan Pengembangan Edisi Keempat. Jakarta: Kencana Prenada Media Group.

Siregar, Syofian. 2015. Statistika Terapan untuk Perguruan Tinggi Edisi Pertama. Cetakan Pertama.Jakarta: Prenada Media Group.

Sudijono, Anas. 2005. Pengantar Evaluasi Pendidikan. Jakarta: PT Grafindo Persada.

Sukada, dkk. 2013. "Kontribusi Minat Belajar, Motivasi Berprestasi, dan Kecerdasan Logis Matematika Terhadap Hasil Belajar Matematika Siswa SMA Negeri 1 Kintamani”, Volume 4. http://pasca.undiksha.ac.id/e-journal/index.php/jurnal ap/article/view/697

Sugiyono. 2009. Metode Penelitian Pendidikan. Bandung: Alfabeta.

Sugiyono. 2013. Statistika Untuk Penelitian. Bandung: Alfabeta.

Sugiyono. 2014. Metode Penelitian Pendidikan. Bandung: Alfabeta.

Sugiyono. 2016. Metodologi Penelitian Pendidikan (Pendekatan Kuantitatif, Kualitatif, dan $R \& D)$. Bandung: Alfabeta.

Sukardi. 2013. Metodologi Penelitian Pendidikan. Jakarta: PT Bumi Aksara

Sukardi. 2015. Evaluasi Pendidikan Prinsip dan Oprasionalnya. Jakarta: PT Bumi Aksara

Susanto, Ahmad. 2013. Teori Belajar dan Pembelajaran di Sekolah Dasar. Jakarta: Prenadamedia Group

Undang-Undang Republik Indonesia no. 20 Tahun 2003 tentang Sistem Pendidikan Nasional, 1990. Jakarta: PT Arnas Duta Jaya.

Wiyani. 2013. Desain Pembelajaran Pendidikan Tata Rancang Pembelajaran Menuju Pencapaian Kompetensi. Yogyakarta: Ar-Ruzz Media.

Yusuf, A. Muri. 2015. Asesmen dan Evaluasi Pendidikan Pilar Penyedia Informasidan Kegiatan Pengendalian Mutu Pendidikan. Jakarta: Kecana. 